\title{
Green value and sustainable transportation engagement: The mediating role of attitude
}

\author{
Nurliyana Nasuha Razalia, Marhana Mohamed Anuar ${ }^{a^{*}}$ and Abdul Hafaz Ngah
}

${ }^{a}$ Faculty of Business, Economics and Social Development, Universiti Malaysia Terengganu, 21030, Kuala Nerus, Terengganu, Malaysia

\section{H R O N I C L E}

\section{Article history:}

Received: June18, 2020

Received in revised format:

August 32020

Accepted: September 8, 2020

Available online:

September 10, 2020

Keywords:

Green value

Sustainable transportation

engagement

Students

Eco-campus

Attitude

\section{A B S T R A C T}

This study aims to investigate the effect of green value on attitude and sustainable transportation engagement and the mediating role of attitude on the relationship between green value and sustainable transportation engagement. A survey was carried out on students in a public university. A sample of 107 students was obtained for this study. The data was analyzed using Partial Least Squares Structural Equation Modelling (PLS-SEM). The findings show that green value and attitude had a significant influence on sustainable transportation engagement. In addition, attitude played a mediating role in the relationship between green value and sustainable transportation engagement. The study provides valuable contributions for both theory and practice in the area of eco-campus. Theoretically, the study extends the value-attitudebehavior model in the context of sustainable transportation and adds to the body of literature of ecocampus. This is among the first studies conducted in Malaysia that investigates factors that contribute towards sustainable transportation engagement among students. In terms of managerial significance, the results provide guidance to policymakers to help them plan for strategies to enhance students' engagement in sustainable transportation in the future.

\section{Introduction}

The key to a sustainable city is sustainable transportation (Wadhwa, 2000). This is due to excessive air pollution and noise from unsustainable transportation. Since 1960, emissions per kilometer have been decreased but in many urban areas, the percentage of traffic growth rise above that of improving emissions managements. Full recycling may be needed for solid waste, fluids, scrapped vehicles, and infrastructure. Many recognize the toll of deaths and injuries in accidents as a sustainability problem (Greene, 2015). It is widely acknowledged that trends in motorization on universities equate those experienced by the community at large. The carbon content of transportation fuels and the energy performance of transport systems influence the quantity of carbon dioxide emission produced by transportation. Greene (2015) points out that the combustion of fossil fuels is the prevalent cause of greenhouse gas emissions from human activities. Transportation is directed on an unsustainable lane. It is the rapid growing source of greenhouse gas emissions due to people action. Rises in the number of new vehicles, the average size of vehicle and the distance they are driven each year have been steadily increased in ground-level ozone and particulates in cities, regardless of compact vehicle emissions regulations (Wadhwa, 2000). Vasquez et al. (2015) report that few peer-reviewed studies analyze greenhouse gas emissions produced by universities for developing countries. It is estimated from their study that the GHG emission values at the campus expected to be increased in the future. This is because universities are developing and become more complicated. Besides, it is the regular path to move toward a higher economic level that is predicted in developing countries and middle-income countries which affects, among other things, greater access to automobiles for the students. during the last decade, campus planners have managed to provide access and

\footnotetext{
* Corresponding author.

E-mail address: marhana@umt.edu.my (M. M. Anuar) 
mobility without destroying campus qualities as distinct communities (Balsas, 2003). Any university working towards sustainability must compromise with the concern of transportation as students, staff and visitors commuting to and from campus represent one of the most crucial impacts a university has on the environment and society (Miralles-Guasch \& Domene, 2010). Specifically, the current trends in transport activity volume and growth pose serious barriers for societies addressing to shift towards sustainable development (OECD, 1996). Towards sustainable development, generations must not compromise the ability of future generations to meet their needs (Greene, 2015). Hence, in terms of environmental issue in eco-campus for this paper, 'sustainable transport' has become the main goal for transport planning and policymaking around the world (Chowdhury \& Ceder, 2016). Environmental issues on public transport and eco-campus for sustainability have been the preferences for Malaysian public universities, especially in assuring the efficiency and effectiveness of the bus service (Hashim, et al., 2013). This is because to become leaders in sustainable development, universities need to prepare students and "practice what they preach" (Gomez, et al., 2016). So, the aims of this study are

i) to examine the effect of green value on attitude,

ii) to examine the effect of attitude on sustainable transportation engagement,

iii) to examine the mediating role of attitude on the relationship between green value and sustainable transportation engagement.

\section{Literature review}

\subsection{Sustainable transportation engagement}

Sustainable transportation can be explained as satisfying present transport and mobility requirements without negotiating the ability of future generations to meet these needs (Black, 1996). In the context of this research, the Sustainable Transportation Engagement (STE) can be defined as the process whereby higher education makes deliberate attempts to involve and empower students in satisfying current transport and mobility needs without compromising the ability of future generations to meet such needs. Transportation at the university used by students can be categorized into: a) private vehicles, public transport, university transit bus, bicycles and walking. Black (1997) in his journal article stated that there are several reasons for unsustainable transportation such as the limited nature of petroleum supplies, the bad effects of petroleum-based emissions on air quality, the number of fatalities and injuries because of motor vehicles, traffic congestion, bordering on gridlock in many cities, and urban sprawl. The negative impacts of petroleum-based emissions on air quality is very dangerous not only for human health but also environment including animal life (Azam, et al., 2016). A sustainable transportation system has defined by The Transportation Association of Canada as a system that (Wadhwa, 2000) meets the access requirements of the current generation; giving chances for future generations to meet their own access needs (which will grow because of economic development and increasing populations); is powered by renewable (inexhaustible) energy resources; does not contaminate air, land or water beyond the planet's capability to ingest/purify (especially CO]); is technologically achievable; is economically and financially cost-effective; supports a craved quality of life; supports local, national and worldwide sustainable development goals.

\section{Value-Attitude-Behavior Model}

This study used value-attitude-behavior model as an underlying theory. Values are mostly expressed in terms of good or bad, better or worse, desirability or avoidance. Values define or direct us to goals, frame our attitudes, and provide standards against which the behavior of individuals and societies can be judged. Consumers' environmental consciousness (value) strongly influenced their attitude towards environmental issues and towards eco-social benefits (attitude), which in turn exerted positive effects on their green purchase behavior (behavior) (Cheung \& To, 2019). In the context of transportation, human behavior on the road is determined by the attitude to driving, the psychological condition at the moment of driving, the cognitive processes, and the personality (Muzikante \& Rengge, 2011).

\section{Green value}

Values are related to the beliefs and concepts that govern a specific desirable state and, in turn, can affect behavior (Bardi \& Schwartz, 2003). The previous study by Karna, Hansen and Juslin (2003) reported that green values, environmental marketing strategies, structures and functions are logically connected. Based on the concept of green or ecological marketing, businesses should refer to ethical and green practices while dealing with customers, suppliers, dealers, and employees (Rehman, 2017). Values convey what is significant to us in our lives. Every individual has various values (e.g., achievement, benevolence) with changeable degrees of importance (Bardi \& Schwartz, 2003). In this study, student as the largest stakeholder in higher education should practice green value for sustainable transportation to achieve sustainable development. Environmental or "green" marketing has been seen as a tool towards sustainable development and satisfaction of different stakeholders (Karna, et al., 2003).

\section{Attitude}

Attitudes refer to the evaluation of a specific object, quality, or behavior as good or bad, positive or negative (Leiserowitz, et al., 2006). It is usually extracted from and reflect abstract values (Maio et al., 2013). Attitude, as well as behaviors, are leaded, 
commonly by the beliefs that are reachable in the context in which attitudes are expressed and in the context in which behavior is performed (Ajzen I. , 2012). In line with VAB model, attitude is expected to mediate the relationship between green value and STE. This study is therefore among the first few studies that this relationship.

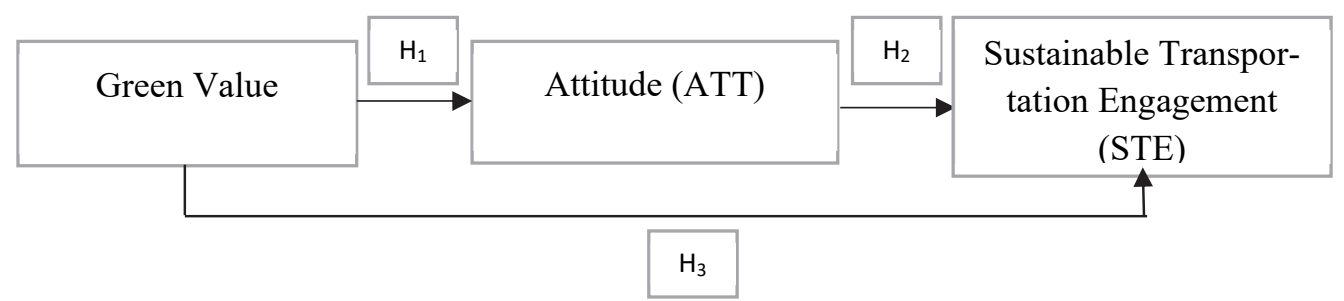

Fig. 1. Research model

Based on the literature review conducted the following hypotheses are proposed.

H1: Green value positively influences attitude.

H2: Attitude positively influences sustainable transportation engagement.

H3: Attitude mediates the relationship between green value and sustainable transportation engagement.

\section{Methodology}

\section{Sample and data collection}

Quantitative research using convenience sampling method was used in this study. Survey data was collected through the personal delivery of self-administered survey forms on March 2019 to random students who were around the main library of University Malaysia of Terengganu. This study utilized Gpower software to reach the minimum sample size needed. The sample size necessary for two independent variables and two dependent variables using effect size (f2) of 0.15 (medium) is 68 respondents. However, a total of 130 questionnaires were distributed to University Malaysia of Terengganu's students as one of the top eco-campus in the UI Green Metric for east of Malaysia (Anon., 2018). One Hundred and seven were returned which were considered suitable for the analysis, yielding a response rate of 82.31 per cent. 23 of these were rejected due to errors in completing sections of the questionnaire.

\section{Measurement Items}

The distributed questionnaire consists of three sections. The instruments involving 14 items related to the research model were adapted from existing literature and refined based on the context of this study.

In section A, the respondents were asked about mode of transportation on campus, frequency of use and sustainable transportation engagement with eight items specifically in environmental sustainability using five-point Likert-scale $(1=$ strongly disagree and $5=$ strongly agree). In section $\mathrm{B}$, the green value and attitude were measured through a five-point Likert-scale $(1=$ very seldom and $5=$ very often $)$ with three items for green value adopted from Choi, Jang, \& Kandampully (2015) and three items for attitude adopted from Taufique \& Vaithianathan (2018). In section C, the respondents were asked about their gender, age, nationality, year of study, the program of study, courses on environment taken, car ownership, purchased parking pass, residence, student status, religion and race. A pre-test allowed for the quotation of comments and recommendations regarding potential defect including the questionnaire format, design, and wording.

\section{Data Analysis}

Data does not have the normality requirement when it is analyzed with Smart PLS. However, as suggested by Hair et al. (2017), the study was tested for the multivariate normality by looking at the skewness and kurtosis using the software available at:

https://webpower.psychstat.org/models/kurtosis/results.php?url=54750fdd23ccb0c263171592f2a06b89.

If the distribution is normal, the values of skewness and kurtosis are zero. Kurtosis values above zero indicate a distribution that is too peaked with short, thick tails, and kurtosis values below zero indicate a distribution that is too flat (also with too many cases in the tails). Non-normal kurtosis produces an underestimate of the variance of a variable (Tabachnick $\&$ Fidell, 2007). The findings displayed the research data was multivariate, not normal, Mardia's multivariate skewness $(\beta=0.000$, $\mathrm{p}>0.01)$ and Mardia's multivariate kurtosis $(\beta=1.780, \mathrm{p}>0.01)$, which is a non-parametric analysis software. The Partial Least Squares (PLS) analysis (using the SmartPLS 3.2.8 software) was used to analyze the measurement model (Ringle, et al., 2015). There are two recommended stage analytical procedures. First is the measurement model (validity and reliability of 
the measures) (Anderson \& Gerbing, 1988). Second, the examination of the structural model (testing the hypothesized relationship) (Hair Jr, Sarstedt, Hopkins, \& Kuppelwieser, 2014).

\section{Findings}

\section{Respondents profile}

Among the respondents, $23.4 \%$ of students were male and $76.6 \%$ were female. Respondents mostly had an age range from below 24 years old (88.8\%), 9.3\% were $24-26$ years old, $0.9 \%$ for $27-29$ years old and also $0.9 \%$ for over 29 years old. The most mode of transportation used by the respondents in this study is a walk (51.4\%), followed by motorcycle (23.4\%), drove alone (10.3\%), carpool (9.3\%), public transportation (2.8\%) and others $(2.8 \%)$.

Table 1

Demographic Profiles of the Respondents

\begin{tabular}{|c|c|c|c|}
\hline Variables & Category & Frequency & Per cent $(\%)$ \\
\hline \multirow[t]{2}{*}{ Gender } & Male & 25 & 23.4 \\
\hline & Female & 82 & 76.6 \\
\hline \multirow[t]{4}{*}{ Age } & Below 24 years old & 95 & 88.8 \\
\hline & $24-26$ & 10 & 9.3 \\
\hline & 27-29 years old & 1 & .9 \\
\hline & Over 29 & 1 & .9 \\
\hline \multirow[t]{2}{*}{ Nationality } & Malaysian & 104 & 97.2 \\
\hline & Non-Malaysian & 3 & 2.8 \\
\hline \multirow[t]{4}{*}{ Study year } & 1 year & 39 & 36.4 \\
\hline & 2 years & 24 & 22.4 \\
\hline & 3 years & 34 & 31.8 \\
\hline & More than 3 years & 10 & 9.3 \\
\hline \multirow[t]{3}{*}{ Program of study } & Bachelors & 102 & 95.3 \\
\hline & Masters & 2 & 1.9 \\
\hline & $\mathrm{PhD}$ & 3 & 2.8 \\
\hline \multirow[t]{2}{*}{ Environment course has taken } & Yes & 54 & 50.5 \\
\hline & No & 53 & 49.5 \\
\hline \multirow[t]{2}{*}{ Car ownership } & Yes & 24 & 22.4 \\
\hline & No & 83 & 77.6 \\
\hline \multirow[t]{2}{*}{ Purchased parking pass } & Yes & 18 & 16.8 \\
\hline & No & 89 & 83.2 \\
\hline \multirow[t]{2}{*}{ Residence } & On-campus & 60 & 56.1 \\
\hline & Off-campus & 47 & 43.9 \\
\hline \multirow[t]{2}{*}{ Student status } & Full-time & 105 & 98.1 \\
\hline & Part-time & 2 & 1.9 \\
\hline \multirow[t]{4}{*}{ Religion } & Islam & 80 & 74.8 \\
\hline & Buddhism & 16 & 15.0 \\
\hline & Hinduism & 7 & 6.5 \\
\hline & Christian & 4 & 3.7 \\
\hline \multirow[t]{4}{*}{ Race } & Malay & 77 & 72.0 \\
\hline & Indian & 19 & 17.8 \\
\hline & Chinese & 7 & 6.5 \\
\hline & Other & 4 & 3.7 \\
\hline
\end{tabular}

\section{Types of transportation mode}

Table 2 demonstrates types of transportations that students used on campus. Majority of the students $(51.4 \%)$ preferred to walk within campus, followed by using own transport such as motorcycles $(23.4 \%)$ and car $(10.3 \%)$. A few students $(9.3 \%)$ using a share vehicle-carpool and the least popular mode of transport was using a public transportation. Perhaps, the high cost of using a public transport contributed to the low popularity of this transportation mode among students at the university.

Table 2

Transportation mode in campus

\begin{tabular}{|c|c|c|c|}
\hline & & Frequency & Per cent \\
\hline \multirow[t]{6}{*}{ Valid } & Walk & 55 & 51.4 \\
\hline & Motorcycle & 25 & 23.4 \\
\hline & Public transportation & 3 & 2.8 \\
\hline & Carpool & 10 & 9.3 \\
\hline & Drove alone & 11 & 10.3 \\
\hline & Other & 3 & 2.8 \\
\hline
\end{tabular}


To determine the measurement model two types of validity have been examined which are convergent validity and discriminant validity. The convergent validity of the measurement is commonly decided by examining the loadings, average variance extracted (AVE) and also the composite reliability (CR) at their threshold value. According to Ramayah et al. (2018), the loadings of 0.708 or higher is suggested but loadings higher than 0.5 is adequate if other items have the highest scores of loadings to complement AVE and CR. For AVE, it is suggested that AVE should be higher than 0.5 and CR should be higher than 0.70-0.90 (definitely 0.95) to be considered as satisfactory (Hair J. F., Hult, Ringle, \& Sarstedt, 2017).

In this study, the loadings were all higher than 0.5 . The CR was all higher than 0.7 and the AVE was also higher than 0.5 as suggested in the literature (see Table 3).

The discriminant validity using the new suggested method by Henseler et al. (2015) through the Heterotrait-Monotrait ratio of correlations and the results are shown in Table 4.

\section{Convergent Validity}

Table 3

Validation of measurement scales

\begin{tabular}{|c|c|c|c|c|c|}
\hline Construct & Item & & Loadings & CR & AVE \\
\hline \multirow[t]{3}{*}{ Green value } & $\begin{array}{l}\text { Using sustainable transportation when travelling would enable me to protect } \\
\text { the environment }\end{array}$ & GV1 & 0.900 & \multirow[t]{3}{*}{0.929} & \multirow[t]{3}{*}{0.813} \\
\hline & $\begin{array}{l}\text { Using sustainable transportation when travelling would enable me to prevent } \\
\text { pollution }\end{array}$ & GV2 & 0.891 & & \\
\hline & $\begin{array}{l}\text { Using sustainable transportation when travelling would enable me to respect } \\
\text { the earth }\end{array}$ & GV3 & 0.913 & & \\
\hline \multirow[t]{3}{*}{ Attitude } & $\begin{array}{l}\text { It is very important to raise sustainable transportation concern among campus } \\
\text { communities }\end{array}$ & ATT1 & 0.856 & \multirow[t]{3}{*}{0.875} & \multirow[t]{3}{*}{0.702} \\
\hline & More sustainable transportation initiatives are needed at my campus. & ATT2 & 0.894 & & \\
\hline & It is crucial to promote sustainable transportation among campus communities. & ATT3 & 0.758 & & \\
\hline \multirow{9}{*}{$\begin{array}{c}\text { Sustainable } \\
\text { transportation } \\
\text { engagement }\end{array}$} & I use sustainable transportation to: & & & \multirow{9}{*}{0.948} & \\
\hline & Reduce Carbon Dioxide (CO2) emissions & STEV1 & 0.824 & & \multirow[t]{8}{*}{0.698} \\
\hline & Reduce ozone emissions & STEV2 & 0.919 & & \\
\hline & Reduce Volatile Organic Compound (VOC) emissions & STEV3 & 0.896 & & \\
\hline & Reduce Carbon Monoxide (CO) emissions & STEV4 & 0.874 & & \\
\hline & Reduce Nitrogen Oxides (NOx) emissions & STEV5 & 0.868 & & \\
\hline & Reduce traffic noise level. & STEV6 & 0.662 & & \\
\hline & Reduce energy consumption. & STEV7 & 0.836 & & \\
\hline & Reduce land consumption. & STEV8 & 0.778 & & \\
\hline
\end{tabular}

Notes: CR, composite reliability; AVE, average variance extracted

\section{Discriminant Validity}

In a well-fitting model, Heterotrait correlations should be smaller than Monotrait correlations, meaning that the HTMT ratio should be below 1.0 (Garson, 2016). Henseler, Ringle and Sarstedt (2015) suggested that if the HTMT value is below 0.90 , discriminant validity has been established between a given pair of reflective constructs.

\section{Table 4}

Heterotrait-Monotrait (HTMT)

\begin{tabular}{|c|c|c|c|}
\hline & Attitude & Green value & Sustainable transportation engagement \\
\hline Attitude & & & \\
\hline Green value & 0.355 & & \\
\hline Sustainable transportation engagement & 0.408 & 0.344 & \\
\hline
\end{tabular}

It is important to confirm that there is no collinearity issue in the structural model before testing the structural model. Diamantapoulus and Sigauw, (2006) reported that the VIF must be lower than 3.3. Table 5 below shows the VIF value for each construct is lower than the conservative value of 3.3. Thus, it indicates that collinearity is not a concern (see Table 5).

Table 5

Lateral collinearity

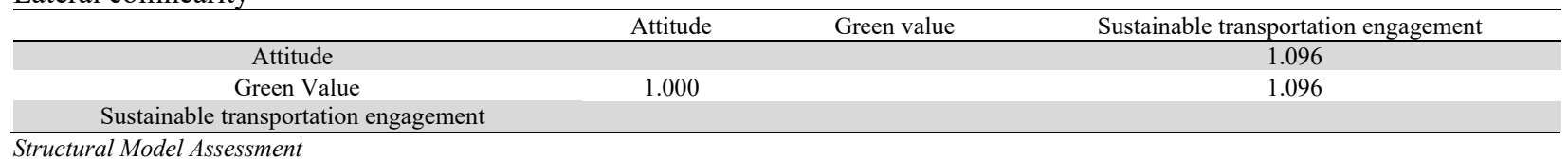


After the measurement model and the collinearity issue were clarified, the assessment of the structural model should be done. To estimate the structural model, a bootstrapping procedure with 500 resamples was run to generate the t-values. Fig. 2 presents the structural model.

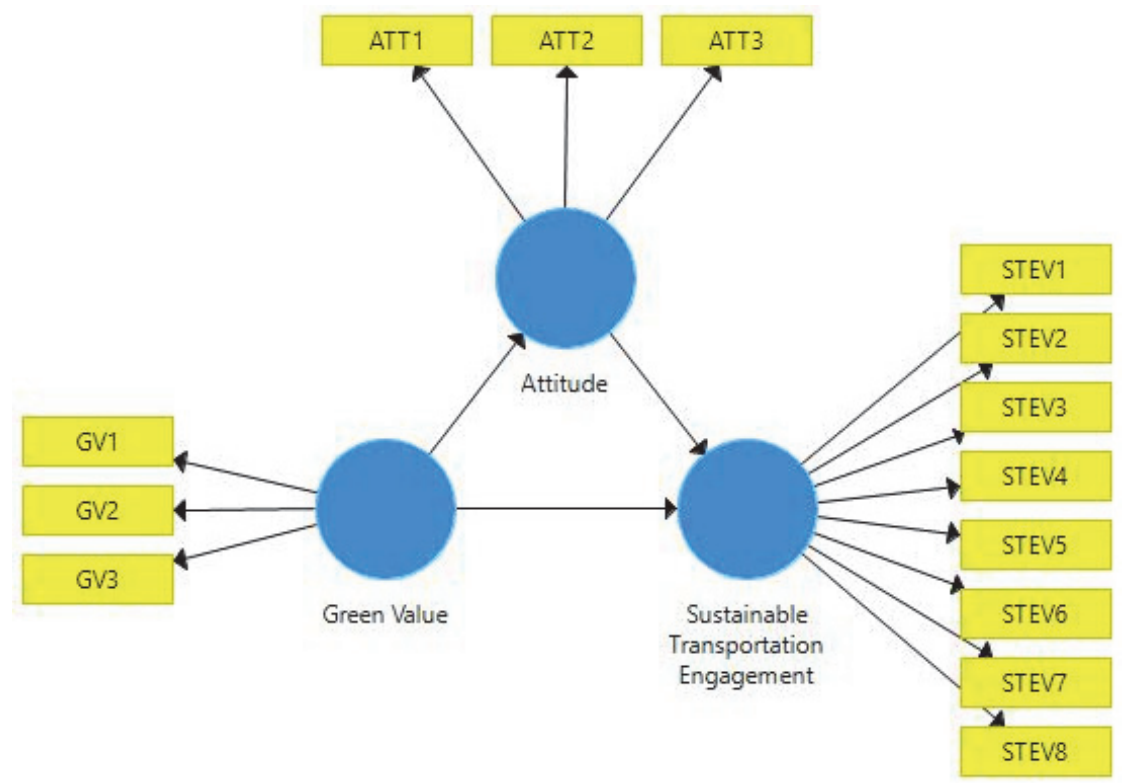

Fig. 2. Structural Model

Table 6 presents the assessment of the coefficient of determination (R2), the effect size (f2) and the predictive relevance (Q2) of the independent variable on dependent variables in this study. The value for the coefficient of determination (R2) for Attitude and Sustainable Transportation Engagement were 0.088 and 0.180 respectively. Overall, the Q2 value of 0.045 and 0.111 for Attitude and Sustainable Transportation Engagement respectively which are larger than 0 (Hair et al., 2014) indicates that exogenous variable has predictive ability over the endogenous variable. For the effect sizes, the endogenous has a small effect size. All the details are shown in Table 6.

Table 6

Assessment of coefficient

\begin{tabular}{lccccc}
\hline Construct & R2 & Q2 & & Effect size & STE \\
GV & & & GV & ATT & 0.061 Small \\
ATT & 0.088 & 0.045 & & 0.096 Small & 0.095 Small \\
STE & 0.180 & 0.111 & & & \\
\hline
\end{tabular}

Notes: GV, Green value; ATT, Attitude; STE, Sustainable transportation engagement

Table 7 illustrates the hypothesis testing results of this study. while Table 7 presents the results of the hypothesis testing. (Green value $\rightarrow$ Attitude), $\beta=0.296, t=3.317, \mathrm{LL}=0.134, \mathrm{UL}=0.442$; (Attitude $\rightarrow$ Sustainable Transportation Engagement), $\beta=0.292, t=3.206, \mathrm{LL}=0.097, \mathrm{UL}=0.463$. Hence, it confirmed that Green value has a positive relationship with Attitude and Attitude has a positive relationship with Sustainable Transportation Engagement. Thus, H1 and H2 were supported.

To test the third hypothesis the Preacher and Hayes (2008) method of bootstrapping the indirect effect was applied. The bootstrapping analysis results for $\mathrm{H} 3$, (Green value $\rightarrow$ Attitude $\rightarrow$ Sustainable Transportation Engagement) $\beta=0.234$, $t=2.150$, $\mathrm{LL}=0.024$, $\mathrm{UL}=0.176$, shows that the relationship were supported. As indicated by Preacher and Hayes (2008), LL and the UL do not straddle a 0 in between indicating there is a mediation effect between the independent variable and the dependent variable. Hence, we can conclude that Attitude (ATT) was mediated a positive relationship between Green value (GV) and Sustainable Transportation Engagement (STE).

Table 7

Hypotheses testing

\begin{tabular}{lllllllll}
\hline Hypothesis & Relationship & Beat & Std. Error & t-value & P-value & LL & UL & Decision \\
\hline H1 & GV $\rightarrow$ ATT & 0.296 & 0.089 & 3.317 & 0.001 & 0.134 & 0.442 & Supported \\
H2 & ATT $\rightarrow$ STE & 0.292 & 0.091 & 3.206 & 0.001 & 0.097 & 0.463 & Supported \\
H3 & GV $\rightarrow$ ATT $\rightarrow$ STE & 0.234 & 0.040 & 2.150 & 0.032 & 0.024 & 0.176 & Supported \\
\hline
\end{tabular}

Notes: GV: Green value, ATT: Attitude, STE: Sustainable transportation engagement 


\section{Discussion and Conclusion}

The results of this empirical study have confirmed that the direct effects of green value on sustainable transportation engagement, the direct effect of attitude on sustainable transportation engagement and the mediation effects of attitude between green value and sustainable transportation engagement exist. The findings gained from the current study are persistent with past studies (Bardi \& Schwartz, 2003; Cheung \& To, 2019), thus affirming that this VAB theory model is potent in predicting sustainable transportation engagement (behavior) among the students in eco-campus.

This study contributes significant understanding as well as theoretical and practical guidance for the forthcoming practice of sustainable transportation in Higher Educations Institutions globally. Theoretically, this paper extends the value-attitude-behavior model in the context of sustainable transportation and adds to the body of literature of eco-campus. It enriched the study of Cheung and To (2019) by confirming that the positive relationship between attitude towards green purchase behavior in terms of environmental sustainability specifically in sustainable transportation on eco-campus. This is among the first studies conducted in Malaysia that examine factors that contribute towards sustainable transportation engagement among students. In terms of policy-making significance, the results accommodate guidance to policymakers to help them plan for strategies to enhance students' engagement in sustainable transportation in the future.

In contempt of the positive findings, the present study was limited in some ways. The sample is selected among students from eco-campus which the result may do not apply to the universities that were not listed as eco-campus in UI Green Metric 2018. However, as time passed by, this surely will develop the understanding among eco-campus students and can increase more universities to participate by implementing sustainable transportation practice towards sustainable development goals 2030 .

\section{Acknowledgement}

The authors would like to thank Universiti Malaysia Terengganu and Ministry of Higher Education Malaysia for supporting this research. This study was conducted under the Fundamental Research Grant Scheme (FRGS), Vote No: 59470.

\section{References}

Ajzen, I. (2012). Values, Attitudes, and Behavior. In: Methods, Theories, and Empirical Application in the Social Science. Springer, pp. 33-38.

Anderson, J. C. \& Gerbing, D. W. (1988). Structural equation modeling in practice: A review and recommended two-step approach. Psychological Bulletin, 103(3), 411-423.

Anon. (2018). UI Green Metric World Universities Ranking.

Azam, A. G., Zanjani, B. R. \& Mood, M. B. (2016). Effects of air pollution on human health and practical measures for prevention in Iran. Journal of Research in Medical Sciences, 21(65).

Balsas, C. J. (2003). Sustainable transportation planning on college campuses. Transport Policy, 10(1), 35-49.

Bardi, A., \& Schwartz, S. H. (2003). Values and behavior: Strength and structure of relations. Personality and Social Psychology Bulletin, 29(10), 1207-1220.

Black, W. R. (1996). Sustainable transportation: a US perspective. Journal of Transport Geography, 4, 151-159.

Black, W. R. (1997). North American transportation: perspectives on research needs and sustainable transportation. Journal of Transport Geography, 5(1), 12-19.

Cheung, M. F., \& To, W. M. (2019). An extended model of value-attitude-behavior to explain Chinese consumers' green purchase behavior. Journal of Retailing and Consumer Services, 50, 145-153.

Choi, H., Jang, J., \& Kandampully, J. (2015). Application of the extended VBN theory to understand consumers' decisions about green hotels. International Journal of Hospitality Management, 51, 87-95.

Chowdhury, S., \& Ceder, A. A. (2016). Users' willingness to ride an integrated public-transport service: A literature review. Transport Policy, 48, 183-195.

Diamantopoulos, A., \& Siguaw, J. A. (2006). Formative versus reflective indicators in organizational measure development: A comparison and empirical illustration. British Journal of Management, 17(4), 263-282.

Garson, G. D. (2016). Partial Least Squares: Regression and Structural Equation Model. Glenn Drive: G. David Garson and Statistical Associates Publishing.

Gómez, N., Cadarso, M. A., \& Monsalve, F. (2016). Carbon footprint of a university in a multiregional model: the case of the University of Castilla-La Mancha. Journal of Cleaner Production, 138, 119-130.

Greene, D. L. (2015). Sustainable Transportation. International Encyclopedia of the Social \& Behavioral Sciences, pp. 845849.

Hair Jr, J. F., Sarstedt, M., Hopkins, L. \& Kuppelwieser, V. G. (2014). Partial least squares structural equation modelling (PLS-SEM) An emerging tool in business research. European Business Review, 26(2), 106-121.

Hair, J. F., Hult, G. T. M., Ringle, C. M. \& Sarstedt, M. (2017). A Primer on Partial Least Squares Structural Equation Modelling (PLS-SEM). Los Angeles: SAGE Publication, Inc.

Hashim, R., Haron, S., Mohamad, S., \& Hassan, F. (2013). Assessment of campus bus service efficacy: an application towards green environment. Procedia-Social and Behavioral Sciences, 105, 294-303. 
Henseler, J., Ringle, C. M., \& Sarstedt, M. (2015). A new criterion for assessing discriminant validity in variance-based structural equation modeling. Journal of the Academy of Marketing Science, 43(1), 115-135.

Karna, J., Hansen, E. \& Juslin, H. (2003). Social responsibility in environmental marketing planning. European Journal of Marketing, 37(5/6), 848-871.

Leiserowitz, A. A., Kates, R. W. \& Parris, T. M. (2006). Sustainability values, attitude, and behaviors: A review of multinational and global trends. Annual Reviews Environment Resources, 31, 413-44.

Maio, G. R., Olson, J. M., Bernard, M. M. \& Luke, M. A. (2003). Ideologies, Values, Attitudes, and Behavior. New York: Kluwer Academic/Plenum Publisher.

Miralles-Guasch, C., \& Domene, E. (2010). Sustainable transport challenges in a suburban university: The case of the Autonomous University of Barcelona. Transport policy, 17(6), 454-463.

Muzikante, I., \& Rengge, V. (2011). Attitude function as a moderator in values-attitudes-behavior relations. Procedia-Social and Behavioral Sciences, 30, 1003-1008.

OECD (1996). Towards Sustainable Transportation. Canada, s.n.

Preacher, K. J., \& Hayes, A. F. (2008). Asymptotic and resampling strategies for assessing and comparing indirect effects in multiple mediator models. Behavior Research Methods, 40(3), 879-891.

Ramayah, T., Cheah, J., Chuah, F., Ting, H., \& Memon, M. A. (2018). Partial least squares structural equation modeling (PLS-SEM) using smartPLS 3.0. In An Updated Guide and Practical Guide to Statistical Analysis. Pearson.

Rehman, A. U. (2017). Green values and buying behaviour of consumers in Saudi Arabia: an empirical study. International Journal of Green Economics, 11(2), 154-164.

Ringle, C. M., Wende, S. \& Becker, J. -M. (2015). SmartPLS 3.

Tabachnick, B. G. \& Fidell, L. S. (2007). Using Multivariate Statistics. United States of America: Pearson Education. Inc.

Taufique, K. M. R., \& Vaithianathan, S. (2018). A fresh look at understanding Green consumer behavior among young urban Indian consumers through the lens of Theory of Planned Behavior. Journal of Cleaner Production, 183, 46-55.

Vásquez, L., Iriarte, A., Almeida, M., \& Villalobos, P. (2015). Evaluation of greenhouse gas emissions and proposals for their reduction at a university campus in Chile. Journal of Cleaner Production, 108, 924-930.

Wadhwa, L. C. (2000). Sustainable transportation: the key to sustainable cities. Australia: WIT Press.

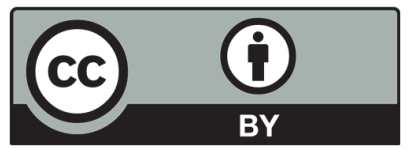

(C) 2020 by the authors; licensee Growing Science, Canada. This is an open access article distributed under the terms and conditions of the Creative Commons Attribution (CC-BY) license (http://creativecommons.org/licenses/by/4.0/). 